\title{
A comparison of extradural tramadol and extradural morphine for postoperative analgesia in female dogs undergoing ovariohysterectomy ${ }^{1}$
}

\author{
Tramadol peridural comparativamente à morfina para analgesia pós-operatória em cadelas \\ submetidas à ovariosalpingohisterectomia
}

\begin{abstract}
Celso Sawaya Neves, Juliana Andrea Osório Balan" ${ }^{\mathrm{II}}$, Diego Roberto Pereira ${ }^{\mathrm{II}}$, Helaine Stevanin ${ }^{\mathrm{III}}$, Renata Navarro Cassu ${ }^{\mathrm{IV}}$
IFellow Master degree, Postgraduate Program in Animal Science, UNOESTE, Presidente Prudente-SP, Brazil. Acquisition of data, helped with technical procedures, collection and processing of study informations, manuscript writing.

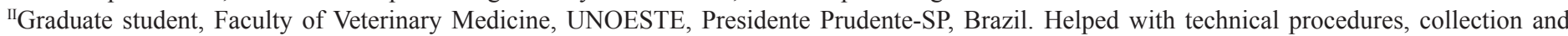
processing of study informations.

IIIFull Professor, Department of Veterinary Surgery and Anestesiology, Scholl of Veterinary Medicine, UNOESTE, Presidente Prudente-SP, Brazil. Responsible for surgical procedures.

${ }^{\mathrm{IV}} \mathrm{PhD}$, Full Professor, Department of Veterinary Surgery and Anestesiology, Scholl of Veterinary Medicine, UNOESTE, Presidente Prudente-SP, Brazil. Mentor. Responsible for intelectual, scientific content and statistical analysis of the study, critical revision.
\end{abstract}

\section{ABSTRACT}

PURPOSE: To compare the postoperative analgesic effects of the extradural tramadol or morphine in female dogs undergoing ovariohysterectomy.

METHODS: Sixteen female dogs were randomly assigned to two groups of eight animals each and received morphine $\left(0.1 \mathrm{mg} \mathrm{kg}^{-1} \mathrm{M}\right.$ group) or tramadol ( $2 \mathrm{mg} \mathrm{kg}^{-1} \mathrm{~T}$ group). The pre-anesthetic medication was intravenously (iv) acepromazine $\left(0.05 \mathrm{mg} \mathrm{kg}^{-1}\right)$. Anesthesia was induced with propofol (4mg kg-1iv) and maintained with isoflurane. The degree of analgesia was evaluated using a numerical rating scale that included physiologic and behavior variables. Dogs were scored at one, three, six and 12 hours after surgery by one blinded observer. Dogs were treated with morphine $\left(0.5 \mathrm{mg} \mathrm{kg}^{-1}\right)$ if their scores were $>6$. Serum cortisol was measured before the preanesthetic medication was administered (basal), at the time of the ovarian pedicle clamping (T0), and at 1 (T1), 6 (T6) and 12 (T12) hours postoperative.

RESULTS: The pain score did not differ between morphine and tramadol treatments. Rescue analgesia was administered to one dog in the $\mathrm{T}$ treatment group. Serum cortisol did not differ between treatments.

CONCLUSION: The extradural administration of morphine or tramadol is a safe and effective method of inducing analgesia in female dogs undergoing ovariohyterectomy.

Key words: Analgesics, Opioid. Tramadol. Morphine. Analgesia. Ovary. Hysterectomy. Dogs.

\section{RESUMO}

OBJETIVO: Comparar o efeito analgésico pós-operatório do tramadol em relação à morfina quando utilizados por via peridural em cadelas submetidas à ovariosalpingohisterectomia $(\mathrm{OSH})$.

MÉTODOS: Dezesseis cadelas foram aleatoriamente distribuídas em dois tratamentos, com oito animais em cada, tratadas com morfina $\left(0,1 \mathrm{mg} \mathrm{kg}^{-1}, \mathrm{M}\right)$ e tramadol $\left(2 \mathrm{mg} \mathrm{kg}^{-1}, \mathrm{~T}\right)$. A medicação pré-anestésica foi feita por via intravenosa (iv) com acepromazina $\left(0,05 \mathrm{mg} \mathrm{kg}^{-}\right.$ $\left.{ }^{1}\right)$, seguindo-se indução e manutenção anestésicas com propofol $\left(4 \mathrm{mg} \mathrm{kg}^{-1}\right.$ iv) e isofluorano, respectivamente. O grau de analgesia foi avaliado uma, três, seis e 12 horas após o término da cirurgia, com escala descritiva numérica, que incluiu a observação de alterações fisiológicas e comportamentais. Animais com escore $>06$ foram tratados com morfina $\left(0,5 \mathrm{mg} \mathrm{kg}^{-1}\right)$. A concentração sérica de cortisol foi mensurada antes da sedação (basal), ao término da cirurgia (T0), 1 (T1), 6 (T6) e 12 (T12) horas após a cirurgia.

RESULTADOS: Os escores de dor e a concentração sérica de cortisol não diferiram entre os tratamentos. Analgesia de resgate foi necessária em um cão do tratamento $\mathrm{T}$.

CONCLUSÃO: A administração peridural de morfina e de tramadol resulta em analgesia adequada e de longa duração em cadelas submetidas à ovariosalpingohisterectomia.

Descritores: Analgésicos Opióides. Tramadol. Morfina. Analgesia. Ovário. Histerectomia. Cães. 


\section{Introduction}

Several studies have shown satisfactory results following extradural (ED) opioid administration for postoperative pain relief ${ }^{1-3}$.

The analgesia associated with ED administration of opioids is reportedly of longer duration and higher potency when compared with systemic administration of the same drugs ${ }^{2,4}$. Additionally, the incidence of adverse effects, such as respiratory depression, bradycardia, vomiting, and urinary retention, is lower after ED administration when compared with parenteral administration ${ }^{5,6}$. Thus, many opioid drugs have been investigated for ED administration both in humans ${ }^{7-9}$ and $\operatorname{dog} \mathrm{s}^{1-3,10}$.

Tramadol is a synthetic codeine analog which is a weak $\mu$-receptor agonist ${ }^{11}$. It also inhibits neuronal reuptake of norepinephrine and 5-hydroxytryptamine ${ }^{12}$. The analgesic effects of ED tramadol have been evaluated in human studies ${ }^{7,13-16}$, which have suggested that it is as effective as morphine for moderate pain management.

Although the use of tramadol has become increasingly popular for postoperative pain control in companion animals, only a few studies have evaluated its effects by extradural route in $\operatorname{dogs}^{10,17}$

The purpose of this study was to compare postoperative analgesia of tramadol and morphine following extradural administration for ovariohysterectomy in dogs.

\section{Methods}

This study was approved by the Institutional Animal Research Ethical Committee (protocol number 107/06), and permission for the participation of each dog was obtained from the owner. Sixteen healthy adult, crossbreed, female dogs, which weighed 4.5 to $26 \mathrm{~kg}(11 \pm 12 \mathrm{~kg})$ were evaluated. Animals undergoing elective ovariohysterectomy were selected for this study using a physical examination and laboratory tests (complete blood cell count, urea, creatinine, alanine aminotransferase and aspartate aminotransferase).

After withdrawal of food and water for 12 and 3 hours, respectively, the animals underwent the same anesthesia protocol. All dogs were sedated with $0.05 \mathrm{mg} \mathrm{kg}^{-1}$ of acepromazine maleate (Acepran 0.2\%, Univet, Sao Paulo, Brazil) administered intravenously (IV). Fifteen minutes after sedation, anesthesia was induced with 4 to $5 \mathrm{mg} \mathrm{kg}^{-1}$ (IV) of propofol (Propovan, Cristalia, Itapira, Brazil). The trachea was intubated, and anesthesia was maintained with isoflurane under spontaneous ventilation using a partial rebreathing system (Samurai III, Takaoka, Sao Paulo, Brazil) with an oxygen flow of $1 \mathrm{~L}^{-1} \mathrm{~min}^{-1}$. Ringer's solution $(10 \mathrm{~mL}$ $\mathrm{kg}^{-1} \mathrm{~h}^{-1}$ ) was infused IV using a peristaltic infusion pump (LifeMed, Fars 600, Sao Paulo, Brazil) throughout the surgical procedure.

All dogs were prepared for ED analgesia: hair in the lumbosacral area was clipped, and the dogs were placed in sternal recumbency. Each was randomly assigned to receive $2 \mathrm{mg} \mathrm{kg}^{-1}$ of tramadol (Tramadon, Cristalia, Itapira, Brazil) $(\mathrm{T}, \mathrm{n}=8)$ and $0.1 \mathrm{mg}$ $\mathrm{kg}^{-1}$ of morphine (Tramadon, Cristalia, Itapira, Brazil) $(\mathrm{M}, \mathrm{n}=8)$ by the extradural route. In both treatments, the drugs were diluted with a saline solution to produce a total volume of $0.25 \mathrm{~mL} \mathrm{~kg}$ 1. Extradural injection was performed at the lumbosacral (L7-S1) space. Correct spinal needle placement was confirmed by a lack of resistance to injection ${ }^{3}$. The opioids were injected over a 2 minutes period. All animals underwent routine ovariohysterectomy through a 2 -to 3 - cm midline incision by the same experienced surgeon.

During the anesthetic procedure, end tidal carbon dioxide $\left(\mathrm{PEtCO}^{2}\right)$, inspired carbon dioxide, expired and inspired isoflurane concentration (\%), arterial oxygen saturation of hemoglobin $\left(\mathrm{SpO}^{2 \%} \%\right)$ and heart rate $(\mathrm{HH})$ were measured with a capnograph, pulse oximeter and gas analyzer continuously (VAMOS plus, Dräger, SP, Brazil.). The end-tidal concentration of isoflurane was adjusted on the basis of arterial pressure and heart rate changes as well as using the conventional signs of anesthesia. Systolic arterial blood pressure (SABP) was measured by noninvasive method using a Doppler ultrasonic (Doppler 841-A, Parks Medical Electronics, Las Vegas, EUA).

During the first 12 hours postoperative, the animals underwent a blind evaluation of the analgesia degree using a numerical pain scale ${ }^{18}$, with postoperative measurements at 1 , 3, 6 and 12 hours. Pain scores were assigned, and the maximum possible scores obtained was 20 (Table 1). 
TABLE 1 - Criteria used for scoring postoperative pain in dogs.

\begin{tabular}{|c|c|c|}
\hline Observation & Criteria & Score \\
\hline \multirow{4}{*}{ Heart rate } & $</=10 \%$ above preoperative value & 0 \\
\hline & $11 \%-30 \%$ above preoperative value & 1 \\
\hline & $31 \%-50 \%$ above preoperative value & 2 \\
\hline & $>50 \%$ above preoperative value & 3 \\
\hline \multirow{4}{*}{ Respiratory rate } & $</=10 \%$ above preoperative value & 0 \\
\hline & $11 \%-30 \%$ above preoperative value & 1 \\
\hline & $31 \%-50 \%$ above preoperative value & 2 \\
\hline & $>50 \%$ above preoperative value & 3 \\
\hline \multirow{4}{*}{ Arterial blood pressure } & $</=10 \%$ above preoperative value & 0 \\
\hline & $11 \%-30 \%$ above preoperative value & 1 \\
\hline & $31 \%-50 \%$ above preoperative value & 2 \\
\hline & $>50 \%$ above preoperative value & 3 \\
\hline \multirow[b]{2}{*}{ Salivation } & Normal & 0 \\
\hline & Above normal & 1 \\
\hline \multirow{3}{*}{ Mydriasis } & No & 0 \\
\hline & Yes & 1 \\
\hline & Quiet & 0 \\
\hline \multirow{2}{*}{ Vocalization } & Crying, responds to calming attempts & 1 \\
\hline & Crying no response & 2 \\
\hline \multirow{3}{*}{ Agitation } & Asleep or calm & 0 \\
\hline & Mild agitation & 1 \\
\hline & Moderate agitation & 2 \\
\hline \multirow[b]{3}{*}{ Body position } & Severe agitation & 0 \\
\hline & Sternal and relaxed & 1 \\
\hline & Protecting the incision site, including lateral and fetal position & 2 \\
\hline \multirow{4}{*}{$\begin{array}{l}\text { Response to palpation } \\
\text { of the incision site }\end{array}$} & No response & 0 \\
\hline & Mild response, looks at incision site & 1 \\
\hline & Turns head for the incision site, mild vocalization & 2 \\
\hline & Turns head with intention to bite, severe vocalization & 3 \\
\hline
\end{tabular}

Scores of 0 to 5 indicated mild pain, scores of 6 to 9 indicated moderate pain, and scores of more than 10 indicated severe pain. Additional analgesia was given (intramuscular morphine at $0.5 \mathrm{mg} \mathrm{kg}^{-1}$ ) to dogs that scored 6 or more.

Venous blood samples were collected from the jugular vein to measure of cortisol before the pre-anesthetic medication was administered (basal), at the time of the ovarian pedicle clamping (T0), and at 1 (T1), 6 (T6) and 12 (T12) hours postovariohysterectomy. Serum samples were stored at -70C and analyzed within 12 months after collection. Cortisol levels were quantified using a solid-phase radioimmunoassay (Coat-A-Count Cortisol - DPC, California, USA).

Duration of surgery and time to endotracheal extubation were recorded as well as the occurrence of adverse effects such as nausea, vomiting, tremors, excitement and drooling.

Data were recorded as mean $\pm \mathrm{SD}$. The data analyzed using an analysis of variance with the F test followed by Tukey's test using Graphpad software. Differences between treatments at each time point, differences in time for each treatment, and the interaction between treatment and time were investigated. A P-value less than 0.05 was considered significant.

\section{Results}

There were no differences $(\mathrm{P}>0.05)$ between the groups in terms of mean age (24 and 20 months for the T and $\mathrm{M}$ groups, respectively), body weight ( $16 \pm 8$ and $15.6 \pm 7 \mathrm{~kg}$ for the $\mathrm{T}$ and $\mathrm{M}$ groups, respectively), surgical time ( $40 \pm 3$ and $39 \pm 2$ minutes for the $\mathrm{T}$ and $\mathrm{M}$ groups, respectively) and extubation time ( $5 \pm 3,4.5 \pm 2$ minutes for the $\mathrm{T}$ and $\mathrm{M}$ groups, respectively).

The median pain score did not significantly differ between the tramadol and morphine treatments at any time point (Figure 1). 


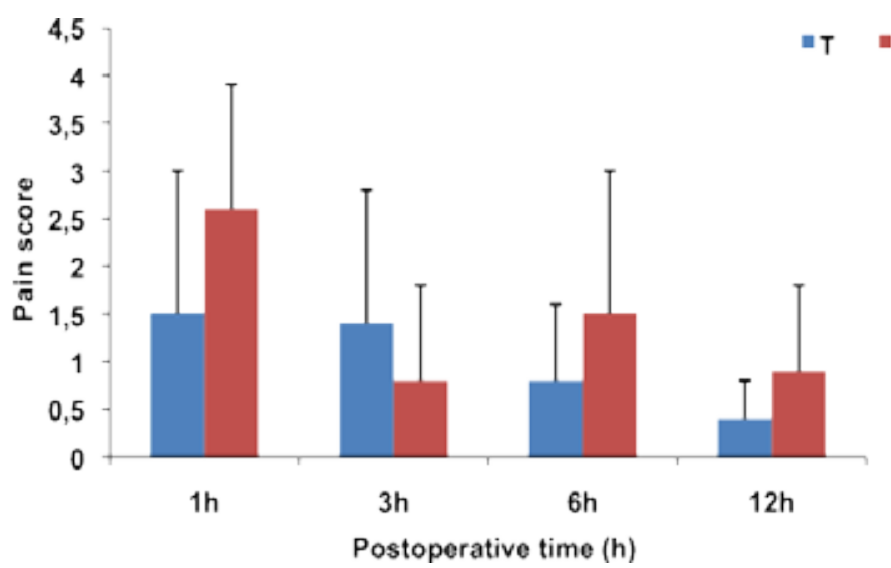

FIGURE 1 - Mean \pm SD pain scores in dogs treated with tramadol $(\mathrm{T})$ and morphine (M) at each time postoperative period.

One dog in the $\mathrm{T}$ group required additional analgesia within 6 hours postoperative. Rescue analgesia was not required by any of the dogs who received morphine.

Serum cortisol concentrations did not significantly differ between treatment groups or times (Figure 2).

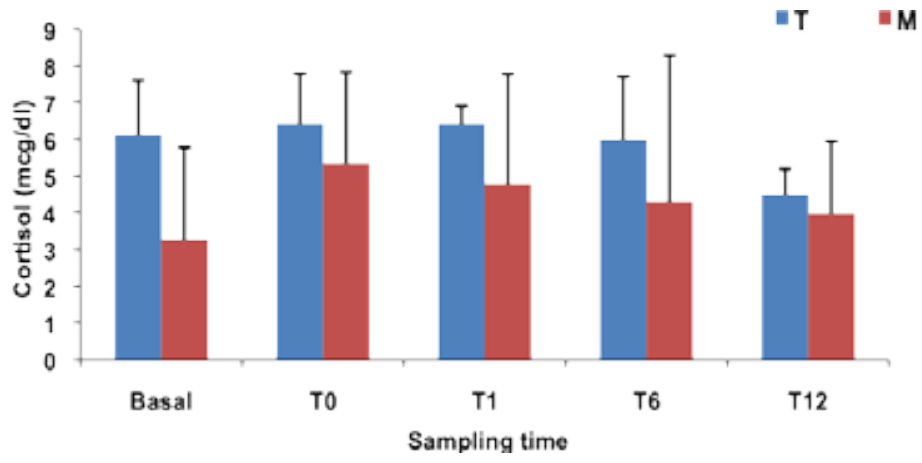

FIGURE 2 - Mean \pm SD serum cortisol concentration in dogs treated with tramadol (T) and morphine (M) at each time postoperative period. T0, at the time of the ovarian pedicle clamping; T1, 1 hour; T6, 6 hours; T12, 12 hours after tracheal extubation.

Undesirable side effects were not observed in any of the dogs.

\section{Discussion}

The current study confirms previous reports in humans ${ }^{7,16}$ and dogs, which have shown similar postoperative analgesia profiles following extradural administration of tramadol or morphine. In both groups, the postoperative pain score was low, and the median values were less than six at 12 hours postoperative, which implies that both regimens provide adequate analgesia for dogs undergoing ovariohysterectomy.

The effects of ED morphine have been well documented in dogs. Several studies have reported the high analgesic efficacy and long duration of action of ED morphine ${ }^{2,5,19,20}$. Nevertheless, a few published studies have described the analgesic properties and the efficacy of extradural tramadol in dogs ${ }^{10,17}$.

Pharmacokinetic and pharmacodynamic studies in humans have demonstrated that the analgesic effects of tramadol result mainly from the actions of the $(+)$ M1 enantiomer ${ }^{21,22}$. According to Vettorato et al. ${ }^{10}$, the pharmacokinetic parameters of intravenous tramadol are equivalent to those produced by extradural tramadol. The rapid and effective production of M1 was observed after both routes of administration. Immediately after tramadol injection, M1 attained concentrations $>10 \mathrm{ng} / \mathrm{mL}$ for a period of eight hours. In humans, this value is considered the lowest concentration associated with therapeutic efficacy ${ }^{20}$. Although this concentration has not been evaluated in dogs, the results of this study and those previously reported ${ }^{10,17}$ demonstrate that tramadol provides satisfactory analgesia during the early postoperative period. In the present study, rescue analgesia was not required for any dogs given ED morphine; this was likely because of the long duration of drug action. The duration of action of extradural morphine in dogs undergoing ovariohysterectomy is at least 16 hours ${ }^{2}$. Regarding tramadol treatment, one dog received additional analgesia at six hours postoperative, while the other dogs in this group did not require rescue analgesia, which is in agreement with other studies ${ }^{10,17}$. Vettorato et al. ${ }^{10}$ have demonstrated that dogs undergoing surgical repair of ruptured cranial cruciate ligaments and treated with ED tramadol do not require rescue analgesia within the first 8 hours of extubation. Almeida et al. ${ }^{17}$ have reported longlasting postoperative analgesia in dogs undergoing orquiectomy. The authors observed similar analgesic effects with ED tramadol/ lidocaine and morphine/lidocaine and no dog required rescue analgesia during the first 24 hours postoperative.

Pain recognition and assessment in animals is challenging because of their inability to communicate, the complexity of pain perception and variation in behavioral responses. Different pain scoring systems have been developed to assess the efficacy of analgesic techniques. Several investigators have reported the use of a variety of scales (visual analog, numerical rating, simple descriptive and composite) developed and correlated specifically for $\operatorname{dog}^{1,23,24}$. The pain scoring system employed in the current study has been previously described for pain quantification in dogs ${ }^{17,18,23}$. In addition, only one observer scored all dogs to avoid interobserver variability in the subjective evaluation.

Other attempts to gather objective data regarding pain and analgesics have included the evaluation of stress-related hormones and metabolites. Previous studies have shown satisfactory 
agreement between pain score and plasma catecholamine and serum cortisol levels ${ }^{25-27}$. In the current study, both tramadol and morphine were effective at preventing the postoperative stress response, using serum cortisol as a guideline. In both treatments groups, serum cortisol did not exceed the reference range $(0.96$ to $6.81 \mathrm{mg} / \mathrm{dl}$ ) at any evaluated time point. In humans, extradural administration of opioids has been shown to have favorable effects on metabolites and hormonal variables in the immediate postoperative period $^{28}$. Previous studies have reported that dogs receiving ED morphine ${ }^{29}$ or ED methadone ${ }^{3}$ have lower postoperative serum cortisol levels than those receiving the same analgesic by IV administration.

In addition to their analgesic effects, both treatments provided satisfactory post-anesthetic recovery. No adverse effects were observed in the current study, which is in agreement with previous results reported in $\operatorname{dog} s^{2,10,17}$.

\section{Conclusions}

The extradural tramadol provides an analgesic effect similar to extradural morphine in dogs undergoing ovariohysterectomy. Additionally, both treatments inhibit the stress response and do not induce adverse effects, resulting in a safe option for analgesia in female dogs.

\section{References}

1. Smith LJ, Yu JK. A comparison of epidural buprenorphine with epidural morphine for postoperative analgesia following stifle surgery in dogs. Vet Anaesth Analg. 2001;28:87-96.

2. Troncy E, Junot S, Keroack S, Sammut V, Pibarot P, Genevois JP, Cuvelliez S. Results of preemptive epidural administration of morphine with or without bupivacaine in dogs and cats undergoing surgery: 265 cases (1997-1999). J Am Vet Med Assoc. 2002;221:66672 .

3. Leibetseder EN, Mosing M, Jones RS. A comparison of extradural and intravenous methadone on intraoperative isoflurane and postoperative analgesia requirements in dogs. Vet Anaesth Analg. 2006;33:128-36

4. Torske KE, Dyson DH. Epidural analgesia and anesthesia. Vet Clin North Am: Small Anim Pract. 2000; 30:860-3.

5. Valverde A, Dyson DH, McDonell WN. Epidural morphine reduces halothane MAC in the dog. Can J Anaesth. 1989;36:629-32.

6. Chaney MA. Side effects of intrathecal and epidural opioids. Can J Anaesth. 1995;42:891-903.

7. Ozcengiz D, Gunduz M, Ozbek H, Isik G. Comparison of caudal morphine and tramadol for postoperative pain control in children undergoing inguinal herniorrhaphy. Paediatr Anaesth. 2001;11:45964.

8. Aribogan A, Doruk N, Aribogan A, Akin S, Balcioglu O. Patientcontrolled epidural analgesia after major urologic surgeries. A comparison of tramadol with or without bupivacaine. Urol Int. 2003; 71:168-75.

9. Axelsson K, Johanzon E, Essving P, Weckström J, Ekbäck G.
Postoperative extradural analgesia with morphine and ropivacaine. A double-blind comparison between placebo and ropivacaine 10 $\mathrm{mg} / \mathrm{h}$ or $16 \mathrm{mg} / \mathrm{h}$. Acta Anaesthesiol Scand. 2005;49(8):1191-9.

10. Vettorato E, Zonca A, Isola M, Villa R, Gallo M, Ravasio G, Beccaglia M, Montesissa C, Cagnardi P. Pharmacokinetics and efficacy of intravenous and extradural tramadol in dogs. Vet J. 2010;183:310-5.

11. Scott LJ, Perry CM. Tramadol: a review of its use in perioperative pain. Drugs. 2000;60:139-76.

12. Dayer P, Collart L, Desmeules J. The pharmacology of tramadol. Drugs. 1994;47(Suppl 1):3-7.

13. Baraka A, Jabbour S, Ghabash M, Nader A, Khoury G, Sibai A. A comparison of epidural tramadol and epidural morphine for postoperative analgesia. Can J Anesth. 1993;40:308-13.

14. Delilkan AE, Vijayan R. Epidural tramadol for postoperative pain relief. Anaesthesia. 1993;48:328-31.

15. Prosser DP, Davis A, Booker PD, Murray A. Caudal tramadol for postoperative analgesia in paediatric hypospadias surgery. $\mathrm{Br} \mathrm{J}$ Anaesth. 1997;79:293-6.

16. Sayyid SS, Maroun MA, Sleimn D, Sfeir M, Baraka A. Epidural tramadol for postoperative pain after cesarean section. Can J Anesth. 1999;46:731-5.

17. Almeida RM, Scobar A, Maguilnik S. Comparison of analgesia provided by lidocaine, lidocaine-morphine or lidocaine-tramadol delivered epidurally in dogs following orchiectomy. Vet Anaesth Analg. 2010;37:542-9.

18. Pibarot P, Dupuis J, Grisneaux E, Cuvelliez S, Planté J, Beauregard G, Bonneau NH, Bouffard J, Blais D. Comparison of ketoprofen, oxymorphone, and butorphanol in the treatment of postoperative pain in dogs. J Am Vet Med Assoc. 1997;211(4):438-44.

19. Kona-Boun JJ, Cuvelliez S, Troncy E. Evaluation of epidural administration of morphine or morphine and bupivacaine for postoperative analgesia after premedication with an opioid analgesic and orthopedic surgery in dogs. J Am Vet Med Assoc. 2006;229(7):1103-12.

20. Pekcan Z, Koc B. The post-operative analgesic effects of epidurally administered morphine and transdermal fentanyl patch after ovariohysterectomy in dogs. Vet Anaesth Analg. 2010;37(6):55765 .

21. Lehmann KA, Kratzenberg U, Schroeder-Bark B, HorrichsHaermeyer G. Postoperative patient-controlled analgesia with tramadol: analgesic efficacy and minimum effective concentrations. Clin J Pain. 1990;6:212-20.

22. Poulsen L, Arendt-Nielsen L, Brosen K, Sindrup SH. The hypoalgesic effect of tramadol in relation to CYP2D6. Clin Pharmacol Ther. 1996;60:636-44

23. Conzemius, MG, Brockman DJ, King LG, Perkowski SZ. Analgesia in dogs after intercostal thoracotomy: a clinical trial comparing intravenous buprenorphine and interpleural bupivacaine. Vet Surg. 1994;23:291-8.

24. Buback JL, Boothe HW, Carroll GL, Green RW. Comparison of three methods for relief of pain after ear canal ablation in dogs. Vet Surg. 1996;25(5):380-5.

25. Sunshine A, Olson NZ, Zighelboim I, De Castro A. Ketoprofen, acetaminophen plus oxycodone, and acetaminophen in the relief of postoperative pain. Clin Pharmacol Ther. 1993;54:546-55.

26. Mastrocinque S, Fantoni DT. A comparison of preoperative tramadol and morphine for the control of early postoperative pain in bitches submitted to ovariohisterectomy. Vet Anaesth Analg. 2003;30:2208 .

27. Martins T, Kahvegian MA, Noel-Morgan J, Leon-Román MA, Otsuki DA, Fantoni DT. Comparison of the effects of tramadol, codeine, and ketoprofen alone or in combination on postoperative 
pain and on concentrations of blood glucose, serum cortisol, and serum interleukin-6 in dogs undergoing maxillectomy or mandibulectomy. Am J Vet Res. 2010;71:1019-26.

28. Hosoda R, Hattori M, Shimada Y. Favorable effects of epidural analgesia on hemodynamics, oxygenation and metabolic variables in the immediate post-anesthetic period. Acta Anaesthesiol Scand. 1993;37:469-74.

29. Popilskis S, Kohn DF, Laurent L, Danilo P. Efficacy of epidural morphine versus intravenous morphine for post-thoractotomy pain in dogs. J Vet Anaesth. 1993;20:21-5.

\section{Correspondence:}

Renata Navarro Cassu

Depto Cirurgia e Anestesiologia

Faculdade Medicina Veterinária e Ciência Animal - UNOESTE

19067-175 Presidente Prudente - SP Brasil

Tel.: (55 18)3229-2077

navarro@unoeste.br

renavarro@uol.com.br

Received: November 22, 2011

Review: January 20, 2012

Accepted: February 22, 2012

Conflict of interest: none

Financial source: none

${ }^{1}$ Research performed at Veterinary Hospital, Department of Veterinary Surgery and Anestesiology, Faculty of Veterinary Medicine, Western Sao Paulo University, Presidente Prudente-SP, Brazil. 